\title{
PENGARUH DISIPLIN IBADAH SHOLAT, LINGKUNGAN SEKOLAH, DAN INTELEGENSI TERHADAP HASIL BELAJAR PESERTA DIDIK MATA PELAJARAN PENDIDIKAN AGAMA ISLAM
}

\author{
THE INFLUENCE OF WORSHIP DISCIPLINE, SCHOOL ENVIRONMENT, AND \\ INTELIGENCE ON STUDENT'S LEARNING RESULT OF THE ISLAM EDUCATION (PAI) \\ LESSON
}

Wahyu Bagja Sulfemi

Program Administrasi Pendidikan STKIP Muhammadiyah Bogor

Jl. Raya Leuwiliang No. 106 Bogor 16640

email: wahyubagja@gmail.com

Naskah Diterima: 9 Mei 2018; Direvisi: 15 Agustus 2018; Disetujui: 28 Agustus 2018

\begin{abstract}
Research aimed to study the worship disciplin analysis, school environment, and inteligence on the student's learning result of the Islam Education (PAI) lesson at Senior High Schools (SMA) in all sub-districts of Pamijahan, Bogor district. This research used survey method with correlation and regression analysis. Population in this research was students from SMA Negeri (Public schools) in all sub-districts of Pamijahan, Bogor district. Meanwhile, samples were 60 students chosen randomly. Data collection obtained by delivering questionnaire and documentation. Data analysis used descriptive statistics, Pearson multiple correlation, coefficient of determination, and regression analysis. Statistical examination used t-test and F-test. Analysis results of worship discipline, school environment, and intelligence on student's learning result of the PAI lesson were: (i) coefficient of correlation 0,865, (ii) coefficient of determination 73,67\%, and (iii) linear regression $\widehat{\mathrm{Y}}=-43,84+0,335 X_{1}+0,283 X_{2}+0,417 X_{3}$. Test analysis showed that the coefficient of correlation and the coefficient of regression is significantly related. It showed the positive and significant relationship between (i) worship discipline, (ii) school environment, and (iii) intelligence and student's learning result of the PAI lesson.
\end{abstract}

Keywords: Intelligence; Learning outcomes; Praying worship discipline; School environment

\begin{abstract}
Abstrak
Penelitian bertujuan untuk mengetahui analisis disiplin ibadah sholat, lingkungan sekolah, dan intelegensi terhadap hasil belajar peserta didik Mata Pelajaran Pendidikan Agama Islam (PAI) di Sekolah Menengah Negeri se-Kecamatan Pamijahan Kabupaten Bogor. Metode penelitian yang digunakan adalah survey dengan analisis korelasi dan regresi. Populasi dari penelitian ini adalah peserta didik SMA Negeri ke-Kecamatan Pamijahan Kabupaten Bogor sedangkan sampel berukuran 60 orang peserta didik yang dipilih secara random. Pengumpulan data dilakukan dengan mengisi kuesioner dan dokumentasi. Analisa data menggunakan statistik deskriptif, korelasi ganda Pearson, koefisien determinan dan analisis regresi. Uji statsitik dipergunakan uji-t dan uji-F. Hasil analisis disiplin ibadah sholat, lingkungan sekolah dan intelegensi, terhadap hasil belajar peserta didik pada mata pelajaran PAI diperoleh koefisien korelasi sebesar 0,865 dan koefisien determinasi sebesar $73,67 \%$, serta persamaan garis regresi $\widehat{\mathrm{Y}}=-43,84+0,335 \mathrm{X}_{1}+0,283 \mathrm{X}_{2}+0,417 \mathrm{X}_{3}$. Melalui analisa pengujian diperoleh bahwa koefisen korelasi dan koefisien regresi tersebut sangat signifikan. Hal tersebut membuktikan bahwa terdapat hubungan yang positif dan sangat signifikan antara disiplin ibadah sholat, lingkungan sekolah dan intelegensi, terhadap hasil belajar peserta didik Mata Pelajaran PAI.
\end{abstract}

Kata kunci: Disiplin sholat; Hasil belajar; Intelegensi; Lingkungan sekolah 


\section{PENDAHULUAN}

Essensi Pendidikan Agama Islam (PAI) pada hakekatnya merupakan proses transfer nilai, pengetahauan, keterampilan dari generasi ke generasi berikutnya yang mencakup dua hal yaitu; pertama, mendidik peserta didik untuk berprilaku sesuai dengan nilai-nilai atau akhlak Islam, kedua mendidik peserta didik untuk mempelajari ajaran Islam berupa pengetahuan tentang ajaran Islam. Salah satu esesensi ini dituangkan dalam hasil belajar yang merupakan kemampuan yang diperoleh anak setelah melalui kegiatan belajar baik bersama guru maupun secara mandiri. Apalagi jika dilihat bahwa Pendidikan Agama Islam menjadi mata pelajaran yang masuk dalam Ujian Sekolah Berstandar Nasional (USBN) dan menjadi penentu kelulusan peserta didik dari satuan pendidikan. ${ }^{1}$

Sekolah sebagai institusi pendidikan harus melakukan pembinaan pendidikan untuk peserta didiknya didasarkan pada kepercayaan dan tuntutan lingkungan keluarga dan masyarakat. ${ }^{2}$ Proses pembelajaran Pendidikan Agama Islam (PAI) khususnya sekolahsekolah menengah (SMA) maupun SMK belum dilaksanakan secara optimal, sehingga perannya sebagai mata pelajaran yang berorientasi pada pembentukan nilai-nilai keimanan dan ketaqwaan kepada Allah SWT serta akhlak mulia belum dapat dicapai secara efektif.

Akan tetapi di satu sisi Mata pelajaran PAI oleh peserta didik dianggap tidak penting bila dibandingkan mata pelajaran yang di UNkan dimana peserta didik sibuk mencari les tambahan untuk untuk mata pelajaran yang diUN sehingga sangat mempegaruhi hasil belajar. Hasil belajar harus dapat menunjukkan suatu perubahan tingkah laku atau perolehan perilaku yang baru dari peserta didik yang bersifat menetap, fungsional, positif dan disadari. Ada berbagai faktor yang dapat mempengaruhi proses dan hasil belajar peserta didik di sekolah yang secara garis besarnya dapat dibagi dalam dua bagian yaitu faktor internal dan faktor eksternal. Faktor eksternal

${ }^{1}$ BNSP, (2018). Tanya Jawab Pelaksanaan Ujian Sekolah Berstandar Nasional (USBN) Tahun Pelajaran 2017/2018. Jakarta: BNSP. P. 5

${ }^{2}$ Hamalik, Omar, (1992). Metode Belajar dan Kesulitan Belajar. Bandung: Tarsito. P. 145. terdiri dari faktor lingkungan dan faktor instrumental. Sedangkan faktor-faktor internal) terdiri faktor fisiologis dan psikologis pada diri peserta $\operatorname{didik}^{3}$.

Kecamatan Pamijahan merupakan kecamatan baru di Kabupaten Bogor. Secara geografis berada dibawah Gunung Salak sehingga memilki udara yang nyaman dan sejuk. Secara kateristik penduduknya mayoritas beragama Islam dan memiliki tingkat religius yang tinggi. faktor religiusitas memiliki kontribusi besar dalam pembentukan karakter dan hasil belajar peserta didik dalam mengimplementasikan nilai-nilai keIslaman dalam kehidupan sehari-hari ${ }^{4}$. Sekolah Negeri biasanya dalam menerima peserta didik melalui seleksi penjaringan sehingga memeliki Inteligensi yang tinggi. Dengan demikian disiplin ibadah shalat, lingkungan sekolah, dan Inteligensi diasumsikan dapat membatu peserta didik dalam meraih prestasi belajar yang maksimal

Berdasarkan latar belakang masalah, maka rumusan masalah penelitin ini adalah sebagai berikut: 1) disiplin Ibadah shalat berpengaruh terhadap hasil belajar PAI, 2) lingkungan sekolah berpengaruh terhadap hasil belajar PAI, 3) Inteligensi berpengaruh terhadap hasil belajar PAI, 4) disiplin ibadah shalat, lingkungan sekolah dan inteligensi, secara bersama-sama berpengaruh terhadap hasil belajar PAI.

Tujuan dari penelitian ini adalah untuk mengetahui pengaruh sebagai berikut: 1) disiplin Ibadah shalat terhadap hasil belajar PAI. 2) lingkungan sekolah terhadap hasil belajar PAI, 3) Inteligensi terhadap hasil belajar PAI. 4) disiplin ibadah shalat, lingkungan sekolah dan inteligensi, secara bersama-sama terhadap hasil belajar PAI peserta didik.

\section{Kajian literatur}

\section{Hasil Belajar Pendidikan Agama Islam (PAI)}

Menurut Anita menyatakan belajar adalah suatu proses dimana suatu organisme

\footnotetext{
${ }^{3}$ Sabri, Alisuf. (1996). Psikologi Pendidikan. Jakarta: Pedoman Ilmu Jaya. P 59.

${ }^{4}$ Uno, H. (2008). Orientasi Baru dalam Psikologi Pembelajaran. Jakarta: Bumi Aksara. P. 143
} 
berubah perilakunya sebagai akibat pengalaman serta merupakan proses perubahan tingkah laku yang diperoleh melalui latihan. Perubahan ini di sebabkan oleh adanya dukungan dari lingkungan yang positif yang menyebabkan terjadinya interaksi edukatif. ${ }^{5}$

Hasil belajar harus menunjukkan suatu perubahan tingkah laku atau perolehan perilaku yang baru dari peserta didik yang bersifat menetap, fungsional, positif dan disadari. Ada berbagai faktor yang dapat mempengaruhi proses dan hasil belajar peserta didik di sekolah yang secara garis besarnya dapat dibagi dalam dua bagian yaitu faktor internal dan faktor eksternal peserta didik. Faktorfaktor yang berasal dari luar diri peserta didik (eksternal) terdiri dari faktor lingkungan dan faktor instrumental. Sedangkan faktor-faktor yang berasal dari dalam diri peserta didik (internal); adalah berupa faktor fisiologis dan psikologis pada diri peserta $\operatorname{didik}^{6}$. Hasil belajar tertuang dalam taksonomi Bloom, yakni dikelompokkan dalam tiga domain yaitu domain kognitif atau kemampuan berpikir, domain afektif atau sikap, dan domain psikomotor atau keterampilan. Hasil belajar seseorang dapat dilakukan melalui pengukuran melalui tes dan pengukuran. Keduanya sebagai dengan alat dalam mengumpulkan data yang disebut dengan instrumen penilaian hasil belajar. 7

Dalam Garis-Garis Besar Program Pembelajaran (GBPP) PAI merupakan usaha sadar untuk menyiapkan peserta didik dalam meyakini, memahami, menghayati, dan mengamalkan agama Islam melalui kegiatan bimbingan, pembelajaran, atau latihan untuk menghormati agama lain dalam hubungan kerukunan antar umat beragama dalam masyarakat untuk mewujudkan persatuan nasional. ${ }^{8}$ PAI memberikan tuntunan bahwa agama diajarkan kepada manusia dengan visi untuk mewujudkan manusia yang bertakwa

${ }^{5}$ Anitah W, Sri dkk, (2014). Strategi Pembelajaran di SD Tangerang Selatan: Universitas Terbuka, P. 1.3

${ }^{6}$ Sabri, Alisuf. (1996). Psikologi Pendidikan. Jakarta: Pedoman Ilmu Jaya, P. 59.

${ }^{7}$ Sudjana, (2009). Penilaian Hasil Proses Belajar Mengajar. Bandung: PT. Ramaja Rosdakarya, P. 22

${ }^{8}$ Muhaimi, et.al. (2001). Paradigma Pendidikan Islam: Upaya Mengefektifkan Pendidikan Agama Islam di Sekolah. Bandung: Remaja Rosdakarya, P. 75 kepada Allah Swt. dan berakhlak mulia, serta bertujuan untuk menghasilkan manusia yang berbudi pekerti, etis, jujur, adil, menghargai, disiplin, harmonis dan produktif, baik secara personal maupun sosial. PAI memilki tujaun untuk menghasilkan manusia yang menyempurnakan iman, takwa, dan akhlak, serta aktif membangun peradaban dan keharmonisan kehidupan, khususnya dalam memajukan peradaban bangsa yang bermartabat. $^{9}$

Mata pelajaran PAI jika dirumuskan mengandung pengertian bahwa proses PAI yang dilalui dan dialami oleh peserta didik di sekolah dimulai dari tahapan kognisi, yakni pengetahuan dan pemahaman peserta didik terhadap ajaran-ajaran dan nilai-nilai yang terkandung ajaran Islam, menuju ke tahapan afeksi, yakni terjadinya proses internalisasi ajaran dan nilai agama ke dalam diri peserta didik, dalam arti menghayati dan meyakininya. Tahapan ini berkaitan dengan kognisi, karena keyakinan dan penghayatan peserta didik akan menjadi kokoh jika dilandasi oleh ilmu, pengetahuan dan pemahamannya terhadap ajaran dan nilai agama Islam. Tahapan afeksi dapat menumbumbuhkan motivasi dalam diri peserta didik dan tergerak untuk mengamalkan dan menaati ajaran Islam sebagai tahapan psikomotorik yang telah diinternalisasikan dalam dirinya sehingga terbentuk manusia muslim bertakwa, beriman, dan berakhlak mulia.

\section{Disiplin Ibadah Sholat}

Disiplin berasal dan bahasa dalam Latin disciplina yang berarti pengajaran atau latihan. Ada juga yang mengatakan berasal dari kata disciple yang berarti pengikut setia, penganut terhadap paham seorang guru, dan ajaran atasi aliran seni. ${ }^{10}$ Ibadah dari bahasa Arab abidaya'budu-'abdan-'ibaadatan yang berarti taat, tunduk, patuh dan merendahkan diri. Taimiyah menyampaikan mencakup segala sesuatu yang dicintai dan diridhai oleh Allah Swt. berupa

${ }^{9}$ Zakiah Daradjat, dkk, (1992), Ilmu Pendidikan Islam, Jakarta; Bumi Aksara, Cet ke-2, P. 76

${ }^{10}$ Poerwadarminta, W. J. S. (2008). Kamus Umum Bahasa Indonesia. Jakarta: Balai Pustaka. P. 237 
perkataan atau perbuatan baik amalan batin ataupun yang dhahir (nyata). ${ }^{11}$

Shalat secara etimologi berarti do'a, sedangkan secara lahiriah beberapa ucapan dan perbuatan yang dimulai dengan takbir dan diakhiri dengan salam, dengan syarat yang telah ditentukan ${ }^{12}$. Lebih lanjut Hasbi Asy Syidiqi menyampaikan bahwa sholat berhadapan hati (jiwa) kepada Allah, yang mendatangkan takut kepada-Nya serta menumbuhkan di dalam jiwa rasa kebesarannya dan kesempurnaan kekuasaanNya. ${ }^{13}$ Menurut Assayuthi ${ }^{14}$, shalat merupakan salah satu sarana komunikasi antara hamba dengan Tuhannya sebagai bentuk ibadah yang di dalamnya merupakan amalan yang tersusun dari beberapa perkataan dan perbuatan yang dimulai dengan takbiratul ikhram dan diakhiri dengan salam, serta sesuai dengan syarat dan rukun yang telah ditentukan syara. Menurut Haryanto $^{15}$ shalat merupakan rangkaian ucapan dan perbuatan (gerakan) yang dimulai dengan takbir dan diakhiri dengan salam, dalam sehari semalam terdiri dari shalat subuh, shalat dzuhur, shalat ashar, shalat maghrib dan shalat isya.

Dengan demikian dapat disimpulkan bahwa kedisipilinan melaksanakan shalat wajib adalah suatu kepatuhan dan kesanggupan menjalankan ibadah shalat dalam sehari semalam sebanyak lima kali dan harus dikerjakan pada waktunya masing-masing dengan tidak meninggalkan satupun waktu sholat.

\section{Lingkungan Sekolah}

Menurut Muhibbin lingkungan sekolah yaitu keadaan sekolah tempat belajar yang turut mempengaruhi tingkat keberhasilan belajar. Keadaan gedung sekolahnya dan letaknya, serta alat-alat belajar yang juga ikut menentukan keberhasilan belajar peserta

\footnotetext{
${ }^{11}$ A Rahman Ritonga Zainuddin. (1997). Fiqh Ibadah, Jakarta: Gaya Mdia Pratama, P.1

${ }^{12}$ Sidi Gazalba. (1975) Asas Agama Islam, Jakarta: Bulan Bintang, P. 88

${ }^{13}$ Hasbi Asy Syidiqi, (1976). Pedoman Shalat, Jakarta: Bulan Bintang, P. 59

${ }^{14}$ Imam Basori Assuyuti, (1998), Bimbingan Shalat Lengkap, Mitra Umat, P. 30

${ }^{15}$ Haryanto, S. (2005). Psikologi Shalat.

Yogyakarta: Pusktaka Pelajar.
}

$\operatorname{didik}^{16}$. Hamalik menyampaikan bahwa lingkungan sekolah adalah suatu lembaga yang menyelenggarakan pengajaran dan kesempatan belajar harus memenuhi bermacam-macam persyaratan antara lain: murid, guru, program pendidikan, asrama, sarana dan fasilitas. Segala sesuatunya telah diatur dan disusun sesuai pola dan sistematika tertentu sehingga memungkinkan kegiatan belajar dan mengajar berlangsung dan terarah pada pembentukan dan pengembangan peserta didik $^{17}$. Selanjutnya menurut Slameto faktorfaktor sekolah yang mempengaruhi belajar mencakup 1) Metode mengajar, 2) Kurikulum, 3) Relasi guru dengan peserta didik, 4) Relasi peserta didik dengan peserta didik, 5) Disiplin sekolah, 6) Alat pelajaran dan, 7) Waktu sekolah. ${ }^{18}$

Dengan demikian untuk menciptakan lingkungan belajar yang efektif perlu adanya kerjasama dan kesesuaian antara kondisi lingkungan belajar dan peserta pembelajaran dalam hal ini peserta didik dan guru. Oleh karena itu perlu ditumbuhkan rasa sadar akan pentingnya lingkungan belajar yang efektif, sehingga tujuan pembelajaran bisa tercapai dengan baik.

\section{Inteligensi}

Menurut Casmini intelegensi berasal dari Bahasa Latin yaitu intelligere yang berati mengorganisasikan, menghubungkan, atau menyatukan satu dengan yang lain (toorganize, to relate, to bind together). Casmini mendefinisikan dua jalan yaitu secara kuantitatif yaitu melalui proses belajar untuk memecahkan masalah yang dapat diukur dengan tes inteligensi, dan secara kualitatif agar berpikir untuk membentuk konstruksi yang menghubungkan dan mengelola informasi dari luar yang sesuai dirinya. ${ }^{19}$ Selanjutnya Efendi ${ }^{20}$, intelegesi adalah

\footnotetext{
${ }^{16}$ Syah, Muhibbin. (2009), Psikologi Pendidikan dengan Pendekatan Baru. Bandung: Remaja Rosdakarya, P.152

${ }^{17}$ Hamalik, Oemar. (2006). Proses Belajar Mengajar. Jakarta: PT Bumi Aksara, p.6

${ }^{18}$ Slameto (.2003).Belajar dan Faktor-faktor yang Mempengaruhiny, .Jakarta:Rineka Cipta. P.64

${ }^{19}$ Casmini. (2007). Emotional Parenting. Yogyakarta: Pilar Media, P.14

${ }^{20}$ Efendi, A. (2005). Revolusi Kecerdasan Abad 21. Bandung: Alfabeta, P 81
} 
kemampuan untuk memecahkan atau menciptakan sesuatu yang bernilai bagi budaya tertentu.

Suryabrata mengelompokkan inteligensi menjadi lima kelompok, yaitu: 1) Konsepsi yang bersifat spekulatif, Dimana konsep ini memandang inteligensi sebagai taraf umum dari sejumlah besar daya khusus; 2) Konsepsi yang bersifat pragmatis, yaiitu inteligensi adalah apa yang dites oleh tes inteligensi (intelligence is what the tests test); 3) Konsepsi yang didasarkan pada analisis faktor, dimana penyelidikan dan pencarian sifat hakikat inteligensi harus mempergunakan teknik analisis faktor; 4) Konsepsi yang bersifat operasional. Konsepsi ini, menyampaikan bahwa faktor-faktor yang mendukung sifat dan hakikat inteligensi sudah diketahui, 5) Konsepsi yang didasarkan pada analisis fungsional. Konsepsi ini menjelaskan bahwa sifat dan hakikat inteligensi disusun berdasarkan bagaimana berfungsinya inteligensi. $^{21}$

Berdasarkan teori tersebut maka dapat disimpulkan inteligensi merupakan salah satu kemampuan manusia yag bersifat potensial dan merupakan kecakapan umum dalam menciptakan sesuatu yang bernilai bagi budaya tertentu. Kecakapan ini dapat terwujud menjadi sebuah kecakapan yang kongkrit dengan bantuan lingkungan.

Dari landasan teoritis dan kerangka berpikir yang telah diuraikan di atas, dapat diajukan hipotesis sebagai berikut 1) Terdapat pengaruh yang signifikan kedisiplinan ibadah sholat terhadap hasil PAI. 2) Tidak terdapat pengaruh yang signifikan kedisiplinan ibadah sholat terhadap hasil belajar PAI. 3) Terdapat pengaruh yang signifikan linkungan sekolah terhadap hasil belajar PAI. 4) Tidak terdapat pengaruh yang signifikan linkungan sekolah terhadap hasil belajar PAI. 5) terdapat pengaruh yang signifikan intelegensi terhadap hasil belajar PAI. 6) Tidak terdapat pengaruh yang signifikan intelegensi terhadap hasil belajar PAI. 7) Terdapat pengaruh yang signifikan kedisiplinan ibadah sholat, lingkungan sekolah dan intelegensi secara

\footnotetext{
${ }^{21}$ Suryabrata, Sumadi. 2002. Psikologi pendidikan. Jakarta: PT Raja Grafindo Persada, P.124 134
}

bersama-sama terhadap hasil belajar PAI. 8) Tidak terdapat pengaruh yang signifikan kedisiplinan ibadah sholat, Lingkungan sekolah dan intelegensi secara bersama-sama terhadap hasil belajar PAI.

\section{METODOLOGI PENELITIAN}

Metode yang digunakan dalam penelitian ini adalah metode survei dengan teknik analisis jalur (path analysis) untuk memperoleh faktafakta dari gejala-gejala yang ada dan mencari keterangan secara faktual ${ }^{22}$ dengan menggunakan pendekatan kuantitatif sebagai tumpuan analisis teknik regresi.

Populasi target dalam penelitian ini adalah seluruh peserta didik SMA Negeri seKecamatan Pamijahan Kabupaten Bogor yang berjumlah 397 peserta didik. Populasi terjangkau dalam penelitian ini adalah seluruh peserta didik kelas XI SMA Negeri 1 Pamijahan Kabupaten Bogor tahun pelajaran 2016/2017 yang berjumlah 154 peserta didik yang terbagi dalam 4 kelas paralel. Teknik pemilihan sampel dalam penelitian ini menggunakan teknik gabungan antara cluster dan random. Teknik cluster digunakan dalam mengelompokkan calon responden menurut kelas paralelnya, sedangkan teknik random digunakan dalam memilih anggota sampel dari setiap cluster yang ada. Jumlah anggota sampel dalam penelitian ini ditetapkan sebanyak 60 orang, karena terdapat 4 kelas paralel maka banyaknya anggota sampel dari setiap kelas adalah 15 peserta didik dengan teknik sample random samplingyaitu pengambilan anggota sampel dari populasi dilakukan secara acak tanpa memperhatikan strata yang ada dalam populasi itu dan cara demikian dilakukan bila anggota pupulasi dianggap homogen. ${ }^{23}$

Penelitian ini dilakukan di SMA Negeri se-Kecamatan Pamijahan karena secara geografis Kecamatan Pamijahan berada dibawah Gunung Salak sehingga memilki udara yang nyaman dan sejuk. Secara kateristik penduduknya mayoritas beragama Islam dan memiliki tingkat religius yang tinggi. faktor

\footnotetext{
${ }^{22}$ Hanun, Farida, 2013. Pengaruh Efikasi Diri, Iklim Kerja, dan Motivasi Berprestasi Terhadap Kinerja Kepala Madrasah (Survey Di Madrasah Ibtidaiyah Kota Bekasi). Jurnal Analisa, 20 (01). 99-114

${ }^{23}$ Sugiyono. 2008. Metode Penelitian Kuantitatif, Kualitatif dan R \& D. Bandung: Alfabeta. P. 82
} 
religiusitas memiliki kontribusi besar dalam pembentukan karakter dan hasil belajar peserta didik dalam mengimplementasikan nilai-nilai keIslaman dalam kehidupan sehari-hari. Selanjutnya biasanya sekolah negeri dalam menerima peserta didik melalui seleksi penjaringan sehingga memeliki inteligensi yang tinggi. Dengan demikian disiplin ibadah shalat, lingkungan sekolah, dan inteligensi diasumsikan dapat membatu peserta didik dalam meraih prestasi belajar yang maksimal. Penelitian ini dilaksanakan lima bulan yaitu mulai dari bulan Mei 2016 sampai dengan bulan September 2016.

Sesuai dengan variabel penelitian, ada empat jenis data yang dikumpulkan, yaitu Hasil Belajar Pendidikan Agama Islam (Y) sebagai variabel terikat (dependent variable), Disiplin Ibadah Shalat $\left(\mathrm{X}_{1}\right)$, Lingkungan Sekolah $\left(\mathrm{X}_{2}\right)$, Inteligensi $\left(\mathrm{X}_{3}\right)$ sebagai variabel bebas (independent variable).

Data hasil belajar PAI peserta didik diambil dari dokumen sekolah yaitu nilai hasil Ulangan Umum Semester I kelas XI tahun pelajaran 2016/2017. Data intelegensi diperoleh dari dokumen sekolah yaitu hasil tes psikologi yang dilakukan oleh lembaga konsultasi psikologi pada saat siswa duduk di kelas X. Data tentang kedisiplinan ibadah sholat dan lingkungan sekolah diperoleh melalui angket/kuesioner.

Instrumen penelitian disiplin ibadah shalat disusun berdasarkan indikator yang terdiri 30 butir pertanyaan yang diuji validitas butir dan reliabilitas instrumen sehingga layak digunakan sebagai intrumen penelitian. Instrumen yang digunakan untuk mengumpulkan data tentang Disiplin Ibadah Shalat berbentuk kuesioner dengan menggunakan rating scale. Model rating scale yang digunakan dalam bentuk kontinum dengan 5 (lima) kategori, yaitu nilai jawaban selalu $=5$, sering $=4$, kadang-kadang $=3$, pernah $=2$, dan tidak pernah $=1$. Semua pertanyaan diatur sedemikian rupa semua bermakna positif.

Instrumen lingkungan sekolah yang terdiri dari 45 butir pertanyaan dengan menggunakan rating scale. Model rating scale yang digunakan dalam bentuk kontinum dengan 5 (lima) kategori, yaitu nilai jawaban selalu $=5$, sering $=4$, kadang-kadang $=3$, pernah $=2$, dan tidak pernah $=1$. Semua pertanyaan diatur sedemikian rupa semua bermakna positif.

Teknik analisis data yang akan digunakan dalam penelitian ini meliputi dua tahap, yaitu: (1) pengujian persyaratan analisis dan (2) pengujian hipotesis penelitian. Sebelum dilakukan pengujian persyaratan analisis, data dari setiap variabel dianalisis deskriptif untuk mendapat gambaran secara umum hasil penelitian. Data yang diperoleh akan disajikan dalam besaran statistik deskriptif seperti rata-rata (mean), nilai tengah (median), frekuensi terbanyak (modus), simpangan baku (standar deviasi). Selanjutnya data disajikan dalam bentuk distribusi frekwensi dan histogram dari masing-masing perlakuan.

Data hasil penelitian yang akan dianalisis dengan menggunakan analisis variansi harus memenuhi persyaratan, yaitu skor galat baku taksiran $\mathbf{Y}$ atas $\mathbf{X}$ berdistribusi normal. Uji normalitas ini dilakukan dengan menggunakan metode Liliefors. Pengujian homogenitas varians berkelompok skor $\mathbf{Y}$ ditinjau dari skor $\mathrm{X}$ dilakukan dengan menggunakan metode Barlett. Pengujian hipotesis dilakukan dengan menggunakan analisis regresi sederhana untuk masing-masing variabel bebas terhadap variabel terikat, dan regresi ganda untuk keseluruhan variabel bebas secara bersamasama dengan variabel terikat, serta korelasional sederhana dan korelasional jamak serta parsial.

Dari landasan teoritis dan kerangka berpikir yang telah diuraikan di atas, dapat diajukan hipotesis sebagai berikut: Pertama, $\mathrm{H}_{0}: \rho_{\mathrm{y} 1}=0$, dan $\mathrm{H}_{1}: \rho_{\mathrm{y} 1}>0$, artinya $\mathrm{H}_{0}$ : tidak terdapat pengaruh yang signifikan kedisiplinan ibadah sholat terhadap hasil belajar PAI dan $\mathrm{H}_{1}$ : terdapat pengaruh yang signifikan kedisiplinan ibadah sholat terhadap hasil PAI. Kedua, $\mathrm{H}_{0}: \rho_{\mathrm{y} 2}=0$ dan $\mathrm{H}_{1}: \rho_{\mathrm{y} 2}>0$, artinya, $\mathrm{H}_{0}$ : terdapat pengaruh yang signifikan linkungan sekolah terhadap hasil belajar PAI dan $\mathrm{H}_{1}$ : tidak terdapat pengaruh yang signifikan linkungan sekolah terhadap hasil belajar PAI. Ketiga, $\mathrm{H}_{0}: \rho_{\mathrm{y} 2}=0$ dan $\mathrm{H}_{1}: \rho_{\mathrm{y} 2}>0$, artinya $\mathrm{H}_{0}$ : terdapat pengaruh yang signifikan intelegensi terhadap hasil belajar PAI dan $\mathrm{H}_{1}$ : tidak terdapat pengaruh yang signifikan intelegensi terhadap hasil belajar PAI. Keempat, $\mathrm{H}_{0}: \rho_{123}=$ 0 dan $\mathrm{H}_{1}: \rho_{123}>0$, artinya, $\mathrm{H}_{0}$ : terdapat 
pengaruh yang signifikan kedisiplinan ibadah sholat, lingkungan sekolah dan intelegensi secara bersama-sama terhadap hasil belajar PAI dan $\mathrm{H}_{1}$ : tidak terdapat pengaruh yang signifikan kedisiplinan ibadah sholat, lingkungan sekolah dan intelegensi secara bersama-sama terhadap hasil belajar.

\section{HASIL DAN PEMBAHASAN}

\section{Deskripsi Data}

Sumber data yang digunakan hasil belajar Pendidikan Agama Islam (Y) adalah dokumen sekolah, yaitu hasil Ulangan Umum Semester II tahun pelajaran 2016/2017. Data hasil belajar diperoleh nilai rata-rata 71,20 dengan simpangan baku 14,71 dan median sebesar 72. Nilai KKM mata pelajaran Pendidikan Agama Islam di SMA Negeri Pamijahan adalah 70, maka banyaknya responden yang tuntas sebanyak 36 orang atau $60 \%$. Jadi jika dilihat dari ketuntasan, maka hasil belajar peserta didik tergolong sedang. Data menunjukkan perbedaan jawaban antar responden termasuk tinggi, responden cukup beragam.

Kuesioner disiplin ibadah shalat ini yang disusun dalam 30 butir pertanyaan yang selanjutnya diuji validitas butir dan reliabilitas instrumen. Hasil validitas butir kuesioner disiplin ibadah sholat $\left(\mathrm{X}_{1}\right)$ menggunakan rumus korelasi product moment pearson, dimana kriteria penerimaan butir instrumen valid atau tidak digunakan uji validitas instrumen dengan $\mathbf{r}_{\text {tabel}}$, yang ditentukan uji satu sisi dengan taraf signifikansi $(\alpha)=0,05$ dan derajat kepercayaan $(\mathrm{df})=\mathrm{k}-2$ (dimana $\mathrm{k}=$ banyaknya responden uji coba). Hasil perhitungan uji coba validitas instrumen butir pertanyaan yang tidak valid dibuang dan tidak digunakan. Untuk perhitungan reabilitas koesioner menggunakan rumus Alpha Cronbach. Angka reliabilitas yang diperoleh dari perhitungan selanjutnya dibandingkan dengan $\mathbf{r}_{\text {tabel }}$ pada uji satu sisi dengan taraf signifikansi Dari hasil perhitungan uji coba reliabilitas instrumen pada diperoleh bahwa instrumen tersebut reliabel.

Berdasarkan angket yang disebar ke reponden diperoleh Skor disiplin ibadah sholat $\left(\mathrm{X}_{1}\right)$ diperoleh rata-rata 100,18 dengan simpangan baku 17,35 dan median 101. Skor rata-rata tiap pertanyaan adalah 3,71 atau $74,21 \%$, ini menunjukkan bahwa rata-rata disiplin ibadah sholat dari para responden termasuk tinggi. Perbedaan jawaban antar responden termasuk tinggi dan para responden cukup beragam. Hasil rata-rata dan dan nilai tengah hampir sama, sehingga penelitian ini cukup representatif dan memiliki sebaran yang cenderung normal.

Hasil validitas butir kuesioner Lingkungan Sekolah $\left(\mathrm{X}_{2}\right)$ menggunakan rumus korelasi product moment pearson, diperoleh nilai $\mathbf{r}_{\text {tabel }}$ adalah 0,3783. Untuk perhitungan reabilitas koesioner digunakan rumus Alpha Cronbach, diperoleh nilai $\mathbf{r}_{\text {tabel }}$ adalah 0.2642. Dari hasil perhitungan uji coba reliabilitas instrumen diperoleh bahwa nilai koefisien korelasi reliabilitasnya adalah sebesar 0,96, yang berarti bahwa instrumen tersebut reliabel.

Hasil Skor Lingkungan Sekolah $\left(\mathrm{X}_{2}\right)$ yang diperoleh dari para responden mempunyai rata-rata 131,75 dengan simpangan baku 18,21 dan median sebesar 134,5. Banyaknya butir pertanyaan dalam instrumen Lingkungan Sekolah adalah 40 butir dengan skor maksimum tiap butir pertanyaan adalah 5, maka skor rata-rata tiap pertanyaan adalah 3,29 atau $65,88 \%$, hal ini menunjukkan bahwa rata-rata skor Lingkungan Sekolah responden termasuk sedang, responden tidak banyak beragam. Dari nilai rata-rata dan dan median menunjukkan penelitian ini cukup representatif sehingga memiliki sebaran yang cenderung normal.

Data Inteligensi $\left(\mathrm{X}_{3}\right)$ diambil dari hasil tes IQ yang dilaksanakan oleh pihak sekolah. Hasil data tersebut diperoleh nilai rata-ratanya 106,08 dengan simpangan baku 10,53 dan median sebesar 105,5. Data ini bisa dikatakan bahwa data inteligensi $\left(X_{3}\right)$ dari para responden termasuk normal. Hasil skor simpangan tersebut menunjukkan perbedaan intelegensi dari responden sedang-sedang saja. Hal ini menunjukkan bahwa data dari responden tidak banyak beragam. Dari nilai rata-rata dan dan nilai tengah yang jauh berbeda, menunjukkan bahwa data intelegensi yang diperoleh cukup representatif dan memiliki sebaran yang cenderung normal.

Hasil pengujian normalitas $\left(\mathrm{X}_{1}\right),\left(\mathrm{X}_{2}\right)$, dan $\left(\mathrm{X}_{3}\right)$ terhadap $(\mathrm{Y})$ berdistribusi normal hal ini yang disajikan dalam Tabel 1. 
Tabel 1. Rangkuman uji normalitas galat baku taksiran $\mathrm{Y}-\widehat{\mathrm{Y}}$

\begin{tabular}{|c|c|c|c|c|}
\hline No. & Galat & L0-maks & Ltabel & Kesimpulan \\
\hline 1 & $\mathrm{Y}-\widehat{\mathbf{Y}_{1}}$ & 0,08473 & 0,1118 & Normal \\
\hline 2 & $\mathrm{Y}-\widehat{\mathbf{Y}_{2}}$ & 0,10883 & 0,1118 & Normal \\
\hline 3 & $\mathrm{Y}-\widehat{\mathbf{Y}_{3}}$ & 0,08953 & 0,1118 & Normal \\
\hline \multicolumn{5}{l}{ Syarat Normal: L0-maks <Ltabel } \\
\hline
\end{tabular}

Dari perhitungan pengujian $\left(\mathrm{X}_{3}\right)$ terhadap $(\mathrm{Y})$ dari populasi yang homogen homogenitas pengelompokan $\left(\mathrm{X}_{1}\right),\left(\mathrm{X}_{2}\right)$, dan (Tabel 2.)

Tabel 2. Rangkuman hasil uji homogenitas

\begin{tabular}{|c|c|c|c|c|}
\hline No. & Galat & $\chi^{2}$ hitung & $\chi^{2}$ tabel & Kesimpulan \\
\hline 1 & Y atas $\mathrm{X}_{1}$ & 0,978 & 3,84 & Homogen \\
\hline 2 & Y atas $\mathrm{X}_{2}$ & 2,848 & 3,84 & Homogen \\
\hline 2 & Y atas $\mathrm{X}_{3}$ & 3,542 & 3,84 & Homogen \\
\hline \multicolumn{5}{|l}{ Syarat Homogen: $\chi^{2}{ }_{\text {hitung }}<\chi^{2}$ tabel } \\
\hline
\end{tabular}

Dari hasil perhitungan diperoleh koefisien korelasi partial antara variabel bebas Disiplin ibadah sholat dengan variabel terikat hasil belajar adalah sebesar 0,757, menunjukkan hubungan kedua variabel tersebut adalah kuat. Sedangkan koefisien determinasi sebesar $57,30 \%$ menunjukkan bahwa besarnya kontribusi Disiplin ibadah sholat mempengaruhi Hasil belajar adalah sebesar $57,30 \%$, sisanya $(42,70 \%)$ karena pengaruh faktor lain. Hasil pengujian signifikansi koefisien korelasi, dari hasil perhitungan diperoleh nilai $t_{\text {hitung }}=8,82$ sedangkan nilai $t_{\text {tabel }}=1,67$. Dengan demikian maka koefisien korelasi tersebut signifikan, dengan kata lain terdapat hubungan yang positif signifikan antara disiplin ibadah sholat dengan hasil belajar. Untuk membuktikan hipotesis tersebut juga dilakukan dengan menggunakan analisis regresi diperhitungan, yaitu diperoleh $\widehat{\mathbf{Y}}=6,91+0,64 \mathrm{X}_{1}$.

Persyaratan linieritas adalah jika $\mathbf{F}_{\text {hitung }}<$ $\mathbf{F}_{\text {tabel }}$ maka garis regresi tersebut linier. Karena nilai $F_{\text {hitung }}=\mathbf{- 2 7 , 9 4}$ sedangkan nilai $F_{\text {tabel }}$ untuk taraf nyata $\alpha=5 \%, \mathrm{n}=60 \mathrm{k}=4$ (dk pembilang= 2 dan $\mathrm{dk}$ penyebut $=58$ ) adalah 2,27 maka $\mathbf{F}_{\text {hitung }}<\mathbf{F}_{\text {tabel, }}$ yang berarti bahwa garis regresi tersebut linier. Karena nilai $F_{\text {hitung }}=\mathbf{7 7 , 8 2 5}$ sedangkan nilai $\mathrm{F}_{\text {tabel }}$ untuk taraf nyata $\alpha=5 \%$, $\mathrm{n}=60 \mathrm{k}=1 \quad(\mathrm{dk}$ pembilang $=1$ dan $\mathrm{dk}$ penyebut $=58$ ) adalah 4,01 maka koefisien regresi tersebut signifikan bahkan cenderung sangat signifikan, sehingga jelas bahwa terdapat pengaruh yang signifikan variabel bebas $\mathrm{X}_{1}$ terhadap variabel terikat $\mathrm{Y}$. Jadi hipotesis di atas adalah benar.

Dari hasil perhitungan diperoleh koefisien korelasi partial antara adalah sebesar 0,718, maka menurut kriteria yang ada menunjukkan bahwa hubungan kedua variabel tersebut adalah kuat. Sedangkan koefisien determinasi sebesar $51,48 \%$ menunjukkan bahwa besarnya kontribusi Lingkungan Sekolah peserta didik mempengaruhi Hasil belajar adalah sebesar 51,48\%, sisanya $(48,52 \%)$ karena pengaruh faktor lain.

Dalam analisis korelasi ini, hipotesis bahwa terdapat hubungan positif antara $\left(\mathrm{X}_{2}\right)$ dengan (Y) diuji melalui uji signifikansi koefisien korelasi dengan menggunakan uji t. Dari hasil perhitungan diperoleh nilai $t_{\text {hitung }}=$ 7,85 sedangkan nilai $t_{\text {tabel }}=1,67$. Dengan demikian terdapat hubungan yang positif dan signifikan antara lingkungan Sekolah dengan hasil belajar.

Hasil perhitungan menggunakan analisis regresi, untuk mengetahui pengaruh $\mathrm{X}_{2}$ terhadap variabel terikat $\mathrm{Y}$ tersebut diperoleh, yaitu $\widehat{\mathbf{Y}}=-5,16+0,58 \mathrm{X}_{3}$. Dari uji signifikansi koefisien regresi dan linieritas garis regresi. Karena nilai $F_{\text {hitung }}=\mathbf{- 2 7 , 9 3}$ sedangkan nilai $\mathrm{F}_{\text {tabel }}$ untuk taraf nyata $\alpha=5 \%, \mathrm{n}=60 \mathrm{k}=4(\mathrm{dk}$ pembilang $=2$ dan $\mathrm{dk}$ penyebut $=58$ ) adalah 2,27 maka $\mathbf{F}_{\text {hitung }}<\mathbf{F}_{\text {tabel, yang berarti bahwa }}$ garis regresi tersebut linier. 
Persyaratan koefisien regresi signifikan adalah jika $\mathbf{F}_{\text {hitung }}>\mathbf{F}_{\text {tabel. }}$. Karena nilai $F_{\text {hitung }}=$ 61,545 sedangkan nilai $F_{\text {tabel }}$ untuk taraf nyata $\alpha=5 \%, \mathrm{n}=60 \mathrm{k}=1$ (dk pembilang= $1 \mathrm{dan} \mathrm{dk}$ penyebut= 58) adalah 4,01 maka $\mathbf{F}_{\text {hitung }}>\mathbf{F}_{\text {tabel, }}$, yang berarti bahwa koefisien regresi tersebut signifikan bahkan cenderung sangat signifikan, sehingga jelas bahwa terdapat pengaruh yang signifikan variabel bebas Lingkungan Sekolah terhadap variabel terikat Hasil belajar. Jadi hipotesis di atas adalah benar. Dari garis regresi tesebut terlihat bahwa karena nilai koefisien regresi $(b)$ positif yaitu 0,58 maka garisnya naik secara terjal, sehingga dapat dikatakan bahwa hubungan variabel bebas lingkungan Sekolah terhadap variabel terikat hasil belajar cukup tinggi.

Untuk membuktikan hipotesis Pengaruh antara Intelegensi terhadap hasil belajar tersebut maka dilakukan pengujian koefisien korelasi. Dari hasil perhitungan pada diperoleh koefisien korelasi partial adalah sebesar 0,662, maka menurut kriteria yang ada menunjukkan bahwa hubungan kedua variabel tersebut adalah kuat. Sedangkan koefisien determinasi sebesar 43,88\% menunjukkan bahwa besarnya kontribusi Intelegensi peserta didik mempengaruhii hasil belajar adalah sebesar $43,88 \%$, sisanya $(56,12 \%)$ karena pengaruh faktor lain. Dalam analisis korelasi ini, hipotesis bahwa terdapat hubungan positif antara Intelegensi dengan hasil belajar. Melalui uji signifikansi koefisien korelasi dengan menggunakan uji t. Dari hasil perhitungan diperoleh nilai $t_{\text {hitung }}=6,73$ sedangkan nilai $t_{\text {tabel }}=1,67$. Hasil analisis regresi, terutama untuk mengetahui pengaruh variabel bebas Intelegensi terhadap variabel terikat hasil belajar diperoleh persaaan regresi yaitu $\widehat{\mathbf{Y}}=$ 26,99+0,926 X 3 .

Untuk menguji hipotesis maka dilakukan uji signifikansi koefisien regresi dan linieritas garis regresi. Persyaratan linieritas adalah jika $\mathbf{F}_{\text {hitung }}<\mathbf{F}_{\text {tabel }}$ maka garis regresi tersebut linier. Karena nilai $F_{\text {hitung }}=\mathbf{- 2 7 , 9 2}$ sedangkan nilai $\mathrm{F}_{\text {tabel }}$ untuk taraf nyata $\alpha=5 \%, \mathrm{n}=60 \mathrm{k}=4(\mathrm{dk}$ pembilang $=2$ dan $\mathrm{dk}$ penyebut $=58)$ adalah 2,27 maka $\mathbf{F}_{\text {hitung }}<\mathbf{F}_{\text {tabel, yang berarti bahwa }}$ garis regresi tersebut linier.

Persyaratan koefisien regresi signifikan adalah jika $\mathbf{F}_{\text {hitung }}>\mathbf{F}_{\text {tabel. }}$ Karena nilai $F_{\text {hitung }}=$ 86,466 sedangkan nilai $F_{\text {tabel }}$ untuk taraf nyata $\alpha=5 \%, \mathrm{n}=60 \mathrm{k}=1(\mathrm{dk}$ pembilang= $1 \mathrm{dan} \mathrm{dk}$ penyebut= 58) adalah 4,01 maka $\mathbf{F}_{\text {hitung }}>\mathbf{F}_{\text {tabel }}$, yang berarti bahwa terdapat pengaruh yang signifikan variabel bebas intelegensi terhadap variabel terikat hasil belajar peserta didik. Dari gambar garis regresi juga terlihat bahwa karena nilai koefisien regresi $(b)$ positif yaitu 0,926 maka garisnya naik secara terjal, sehingga dapat dikatakan bahwa hubungan variabel bebas Intelegensi terhadap variabel terikat hasil belajar cukup tinggi. Jadi hipotesis di atas adalah benar.

Untuk analisis korelasi, dari hasil perhitungan dari program SPSS tabel Model Summary diperoleh koefisien korelasi ganda antara variabel bebas $\mathrm{X}_{1}, \mathrm{X}_{2}$, dan $\mathrm{X}_{3}$ dengan variabel terikat $\mathrm{Y}$ adalah sebesar 0,865 , maka menurut kriteria yang ada menunjukkan bahwa hubungan kedua variabel tersebut adalah sangat kuat. Sedangkan koefisien determinasi sebesar 74,82\% menunjukkan bahwa besarnya kontribusi Intelegensi peserta didik mempengaruhi hasil belajar adalah sebesar $74,82 \%$, sisanya $(25,18 \%)$ karena pengaruh faktor lain.

Dalam analisis korelasi ini, hipotesis bahwa terdapat hubungan positif dan signifikan antara $\mathrm{X}_{1}, \mathrm{X}_{2}$ dan $\mathrm{X}_{3}$ dengan variabel terikat $\mathrm{Y}$ diuji melalui uji signifikansi koefisien korelasi dengan menggunakan uji F. Sesuai hasil perhitungan diperoleh nilai $\mathbf{t}_{\text {hitung }}$ sebesar 55,47. Sedangkan berdasarkan Tabel t untuk taraf nyata $5 \%$, derajat kebebasan $(\mathrm{dk})$ pembilang $=\mathrm{k}$, dan $\mathrm{dk}$ penyebut $=(\mathrm{n}-\mathrm{k}-1)$, dimana $\mathrm{k}$ adalah banyaknya variabel bebas, nilai $\mathbf{t}_{\text {tabel }}$ adalah sebesar 3,16. Persyaratan koefisien korelasi signifikan adalah jika $t_{\text {hitung }}$ $>\mathbf{t}_{\text {tabel }}$, maka terbukti bahwa koefisien korelasi ganda tersebut signifikan. Dengan kata lain benar bahwa terdapat hubungan yang positif dan signifikan antara variabel bebas $X_{1}, X_{2}$ dan $\mathrm{X}_{3}$ dengan variabel terikat $\mathrm{Y}$.

Sedangkan dengan analasis regresi, hubungan fungsional antara $X_{1}, X_{2}$ dan $X_{3}$ dengan $Y$ tersebut juga dapat disajikan dalam bentuk persamaan regresi yang diperoleh $\widehat{\mathbf{Y}}=$ 43,84+0,335 $\mathrm{X}_{1}+0,283 \quad \mathrm{X}_{2}+0,417 \quad \mathrm{X}_{3}$. Karena nilai koefisien regresi $\left(a_{1}, a_{2}\right.$ dan $\left.a_{3}\right)$ positif dan cukup besar yaitu $0,335,0,283$ dan 0,417 hal ini dapat dikatakan bahwa hubungan variabel bebas $\mathrm{X}_{1}, \mathrm{X}_{2}$, dan $\mathrm{X}_{3}$ dengan variabel terikat $\mathrm{Y}$ cukup tinggi. 
Dari hasil perhitungan pengujian signifikansi koefisien regresi yang dilakukan dengan program SPSS tabel ANOVA dimana hasil perhitungan tersebut bisa dilihat pada Tabel 3.

Tabel 3. Hasil perhitungan pengujian signifikansi koefisien regresi ganda

\begin{tabular}{|c|c|c|c|c|c|c|c|}
\hline $\begin{array}{c}\text { Sumber } \\
\text { Variasi }\end{array}$ & Dk & JK & RJK & F hitung & $\begin{array}{c}\mathrm{F}_{\text {tabel }} \alpha= \\
0,05\end{array}$ & $\begin{array}{c}\mathrm{F}_{\text {tabel }} \alpha= \\
0,01\end{array}$ & Kesimpulan \\
\hline Regresi & 3 & 9542,189 & 3180,73 & 55,327 & 2,78 & 4,16 & $\begin{array}{c}\text { sangat } \\
\text { signifikan }\end{array}$ \\
\hline Sisa & 56 & 3219,411 & 57,4895 & & & & \\
\hline Total & 59 & 12761,600 & & & & \\
\hline
\end{tabular}

Persyaratan koefisien regresi signifikan adalah jika $\mathbf{F}_{\text {hitung }}>\mathbf{F}_{\text {tabel. }}$. Karena nilai $F_{\text {hitung }}=$ $\mathbf{5 5 , 5 2 7}$ sedangkan nilai $\mathrm{F}_{\text {tabel }}$ untuk taraf nyata $\alpha=5 \%, \mathrm{n}=60 \mathrm{k}=3$ (dk pembilang= $3 \mathrm{dan} \mathrm{dk}$ penyebut= 56) adalah 2,78 maka $\mathbf{F}_{\text {hitung }}>\mathbf{F}_{\text {tabel }}$, yang berarti bahwa koefisien regresi tersebut signifikan atau dengan kata lain terdapat pengaruh yang signifikan variabel bebas $\mathrm{X}_{1}$ (Disiplin ibadah sholat), $\mathrm{X}_{2}$ (Lingkungan Sekolah), dan $\mathrm{X}_{3}$ (Intelegensi) terhadap variabel terikat Y (Hasil belajar). Jadi hipotesis tersebut benar.

\section{Pembahasan/Interpretasi Hasil Penelitian}

Dari hasil penelitian terdapatnya hubungan positif dan signifikan antara variabel bebas Disiplin ibadah shalat peserta didik SMA Negeri di Kecamatan Pamijahan Kabupaten Bogor dengan variabel terikat Hasil belajar PAI. Hal ini membuktikan bahwa salah satu faktor yang mempengaruhi hasil belajar adalah faktor disiplin ibadah shalat walaupun faktor lain lain yang mempengaruhinya.

Masyarakat Kecamatan Pamijahan Kabupaten Bogor yang religius berdampak kepada kedisiplinan ibadah peserta didik di SMA Negeri Pamijahan. Shalat merupakan pelatihan pembinaan disiplin dan kontrol diri dengan melaksanakan secara tertib dan baik, sikap disiplin akan timbul dengan sendirinya dan melekat kuat dalam diri seseorang. Sikap disiplin ini dapat diterapkan dalam kehidupan sehari-hari. Seorang peserta didik yang melaksanakan ibadah shalat tepat pada waktunya, maka sikap disiplin juga akan melekat kuat dalam diri peserta didik. Tugas seorang peserta didik adalah belajar, sehingga sikap disiplin dapat diterapkan dalam kegiatan belajar di sekolah dan di rumah, Peserta didik dapat mengelompokkan waktu, memanfaatkan waktu luang dan lebih tertib dalam kegiatan belajar. Disiplin ibadah shalat yang baik menciptakan kepatuhan terhadap tugas yang diberikan gurunya. Dengan demikian, jika seorang peserta didik disiplin pula dalam beribadah shalat sehingga tujuan belajar dapat tercapai dengan baik

Menerapkan sikap disiplin pada peserta didik memang tidaklah mudah, diperlukan sikap yang tegas bahkan dapat berujung pada sanksi berupa hukuman. Walaupun diberikan sanksi berkali-kali tetapi tidak membuat peserta didik merasa jera. Kedisiplinan dalam kehidupan sehari-hari memerlukan pembiasaan. Seorang ingin disiplin waktu ia harus membiasakan diri tepat waktu dalam aktivitasnya, Shalat dapat mendidik dari kedisiplinan hingga komitmen terhadap ucapan sikap dan perbuatan.

Peserta didik yang memiliki disiplin ibadah shalat yang baik akan selalu ingat kepada Allah yang memberikan hidup dan kehidupan. Mengingat Allah akan menghindarkan dari segala bentuk kemalasan dan kelesuan, serta rasa tidak tenang dan ketakutan saat melakukan kesalahan dan kelalaian dalam menjalankan kewajiban sehingga peserta didik dapat konsentrasi peserta didik dalam belajar. Dengan ibadah shalat mendidik perbuatan baik, tertib dan jujur sehinggga akan menuntun peserta didik untuk tidak berlaku curang terutama untuk tidak mencontek. Semakin baik mutu shalat peserta didik maka semakin efektiflah dalam membentengi dari perbuatan makasiat. Peserta didik yang shalat dengan khusu tidak akan ditemukan melakukan perbuta zina, maksiat, merampok dan sebagainya, peserta didik mampu menahan untuk tidak berbuat kenakalan seperti membolos sekolah, terpengaruh obat-obatan hingga perilaku 
seksual menyimpang yang mengganggu dalam belajarnya. Peserta didik SMA yang rata-rata remaja dimana ada pada masa puncak emosi dan pencarian jati diri. Kondisi ini dapat dapat dikontrol dengan ibadah sholat sehingga mereka dapat berkonsentrasi dalam belajar.

Dengan demikian peserta didik yang memiliki sikap disiplin yang tinggi dalam mengerjakan ibadah shalat, memiliki tingkat hasil belajar yang tinggi pula. Sebaliknya, peserta didik yang miliki sikap disiplin ibadah shalat yang rendah dalam melaksanakan, maka akan memiliki tingkat hasil belajar PAI yang rendah pula.

Dari perhitungan dimana terdapat hubungan positif dan signifikan antara variabel bebas lingkungan sekolah dengan variabel terikat hasil belajar serta sisa dipengaruhi faktor lainya. Dengan demikian Peserta didik yang berada dalam lingkungan sekolah kondusif umumnya hasil belajarnya bagus. Sebaliknya jika lingkungan yang ada kurang mendukung untuk belajar, maka hasil belajar yang diraih oleh peserta didik juga kurang memuaskan. Hal ini sesuai dengan pendapat dari Ngalim Purwanto (2006:148) bahwa lingkungan sekolah itu mendukung dan berperan besar dalam keberhasilan belajar anak didik. Lingkungan sekolah merupakan segala sesuatu yang berhubungan dengan tempat proses pembelajaran dilaksanakan, sedangkan kondusif berarti kondisi yang benar-benar sesuai dan mendukung keberlangsungan proses pembelajaran. Oleh karena itu, lingkungan Sekolah bagi peserta didik merupakan hal yang sangat penting karena pada hakekatnya belajar adalah berinteraksi dengan lingkungan. Lingkungan sekolah yang nyaman dapat membangkitkan motivasi peserta didik untuk mencapai hasil belajar yang lebih baik. Dengan lingkungan sekolah baik dapat bermanfaat bagi peserta didik yaitu 1) Dapat membuat peserta didik lebih mendalami semua mata pelajaran yang ada di sekolah 2) Membuat peserta didik lebih rajin dalam menuntut ilmu 3) Membuat peserta didik lebih aktif di kelas dan berprestasi di kelas 4) Dapat memberikan peserta didik motifasi belajar di dalam maupun di luar kelas 5) Sebagai wujud kepedulian peserta didik untuk lebih mencintai lingkungan sekitar sekolah 6) Dapat memberikan peserta didik pengalaman belajar di lingkungan luar sekolah. Dari penelitian ini bahwa lingkungan sekolah memiliki hubungan positif dengan hasil belajar. Kondisi ini juga ditunjang oleh kondisi geografis Kecamatan Pamijahan yang berada dibawah kaki gunung Salak yang nyaman, sejuk dan asri

Dari perhitungan terdapat hubungan positif dan signifikan antara variabel bebas Intelegensi dengan variabel terikat Hasil Belajar. SMA negeri biasanya melakukan seleksi terahadap calon peserta didiknya demikian pula dengan peserta didik yang akan masuk ke SMA Negeri yang berada di Kecamatan Pamijahan sudah barang tentu sudah tersaring. Sehingga peserta didik di SMA negeri di Kecamatan Pamijahan memilki intelegensi normal bahkan tinggi. Peserta didik yang memiliki Intelegensi yang tinggi memiliki kemampuan belajar disertai kecakapan untuk menetapkan dan mempertahankan suatu tujuan, untuk mengadakan suatu penyesuaian dalam rangka mencapai tujuan itu dan untuk menilai keadaan diri secara kritis dan objektif. Dengan kemampuan ini memberikan kondisi yang memungkinkan tercapainya pengetahuan, kecakapan, atau keterampilan tertentu setelah melalui suatu latihan oleh peserta didik. Taraf inteligensi ini sangat mempengaruhi hasil belajar seorang peserta didik, di mana peserta didik yang memiliki taraf inteligensi tinggi mempunyai peluang lebih besar untuk mencapai prestasi belajar yang lebih tinggi. Sebaliknya, peserta didik yang memiliki taraf inteligensi yang rendah diperkirakan juga akan memiliki hasil belajar yang rendah. Hipotesisi ini sesuai yang disampaikan Muhibbin (1999)

Dari perhitungan dimana terdapat Hubungan positif dan signifikan antara variabel bebas $X_{1}$ (Disiplin ibadah shalat), $X_{2}$ (lingkungan sekolah), dan $\mathrm{X}_{3}$ (Intelegensi), dengan variabel terikat $\mathrm{Y}$ (hasil belajar). Dengan demikian, jika seseorang terbiasa dengan suasana disiplin dan khusyu' dalam menjalankan sholat maka dalam hal belajar pun juga akan selalu disiplin dan mudah untuk berkosentrasi. Dengan disiplin dan kosentrasi yang tinggi dalam belajar maka niscaya akan diperoleh hasil atau hasil belajar yang tinggi. Lingkungan sekolah merupakan suatu sarana belajar yang penting dan perlu ada dalam sebuah sekolah. Karena tanpa lingkungan 
sekolah semua proses belajar mengajar tidak dapat dilaksanakan dengan baik dan berlangsung tepat. Peserta didik yang memiliki kemampuan atau kekuatan yang dimiliki seseorang untuk menyelesaikan atau memecahkan berbagai masalah yang dihadapinya, sehingga semakin tinggi kemampuan seorang peserta didik dalam menyelesaikan persoalan yang dihadapi maka semakin tinggi pula hasil belajar. Dari penelitian ini bahwa disiplin ibadah sholat, lingkungan sekolah dan intelegensi mempunyai pengaruh yang positif dan signifikan terhadap hasil belajar peserta didik.

\section{PENUTUP}

Berdasarkan deskripsi data penelitian dan setelah dikalukan analisis maka dapat disimpulkan 1). Terdapat pengaruh yang positif dan sangat signifikan disiplin ibadah sholat terhadap hasil belajar peserta didik. 2). Terdapat pengaruh yang positif dan sangat signifikan lingkungan sekolah terhadap hasil belajar peserta didik. 3). Terdapat pengaruh yang positif dan sangat signifikan intelegensi terhadap hasil belajar peserta didik. 4). Terdapat pengaruh yang positif dan sangat signifikan disiplin ibadah sholat, lingkungan Sekolah, dan intelegensi, secara bersama-sama terhadap hasil belajar peserta didik.

Dari simpulan diatas dapat disaran sebagai berikut Pertama, hendaknya para guru, para pengelola lembaga pendidikan, serta para orang tua memperhatikan kedisiplinan peserta didiknya/anaknya dalam menjalankan ibadah. Bagi yang beragama Islam tentunya kedisiplinan dalam menjalankan ibadah sholat, karena menurut hasil penelitian ini kedisipinan dalam beribadah sholat mempunyai pengaruh yang positif dan signifikan terhadap hasil belajar.

Kedua hendaknya para guru, para pengelola lembaga pendidikan, serta para orang tua senantiasa membuat lingkunga sekolah senyaman yang asri, bersih, aman dan nyaman sehingga proses belajar mengajar berlangsung dengan kondusif. sehingga memberikan motivasi kepada peserta didiknya/putranya agar mereka mempunyai semangat belajar, berprestasi dan berkompetisi untuk meraih kesuksesan yang setinggitingginya,
Ketiga hendaknya para guru, para pengelola lembaga pendidikan, serta para orang tua memperhatikan tingkat intelegensi para peserta didik nya/putranya, agar bisa memberi arah pembinaan yang tepat dalam proses pembelajaran, bekal ketrampilan, maupun pembinaan budi pekerti.

Keempat, hendaknya para guru, para pengelola lembaga pendidikan, serta para orang tua bisa memadukan intelegensi, kedisiplinan dalam ibadah sholat, dan motivasi berprestasi dari para peserta didiknya/putranya, agar peserta didiknya/putranya bisa memperoleh hasil belajar yang sebaik mungkin.

\section{UCAPAN TERIMA KASIH}

Penelitian ini terwujud atas bantuan dari banyak pihak. Untuk itu penulis mengucapkan terima kasih kepada SMA Negeri 1 Pamijahan Kabupaten Bogor yang telah menjadi responden dalam penelitian ini. Tak juga penulis mengucapkan terima kasih kepapa Edukasi yang telah bersedia memuat tulisan penulis.

\section{DAFTAR PUSTAKA}

Anitah W, Sri dkk, (2014). Strategi Pembelajaran di SD. Tangerang Selatan: Universita.

Assuyuti, Imam Basori. (1998). Bimbingan Shalat Lengkap, Jakarta: Mitra Umat.

BNSP, (2018). Tanya Jawab Pelaksanaan Ujian Sekolah Berstandar Nasional (USBN) Tahun Pelajaran 2017/2018. Jakarta: BNSP.

Casmini. (2007). Emotional Parenting. Yogyakarta: Pilar Media.

Daradjat, Zakiah. dkk, (1992). Ilmu Pendidikan Islam. Jakarta; Bumi Aksara.

Efendi, A. (2005). Revolusi Kecerdasan Abad 21. Bandung: Alfabeta.

Gazalba, Sidi. (1975). Asas Agama Islam, Jakarta: Bulan Bintang.

Hamalik, Oemar. 2006. Proses Belajar Mengajar. Jakarta: PT Bumi Aksara.

Hamalik, Oemar. (1992). Metode Belajar dan Kesulitan Belajar. Bandung: Tarsito.

Haryanto, S. (2005). Psikologi Shalat. Yogyakarta: Pusktaka Pelajar.

Hanun, Farida, (2013). Pengaruh Efikasi Diri, Iklim Kerja, dan Motivasi Berprestasi 
Terhadap Kinerja Kepala Madrasah (Survey Di Madrasah Ibtidaiyah Kota Bekasi). Jurnal Analisa, 20 (01). 99-114

Karimm, B, (2001), Nilai-nilai Pedagogik dalam Ibadah Sholat, Disertasi, Jakarta: Institut Agama Islam Negeri (IAIN) Syarif Hidayatullah.

Kasim, Anwar. (2005). Bimbingan Konseling Belajar. Jakarta: Universitas Jakarta.

Muhaimi, et.al. (2001). Paradigma Pendidikan Islam: Upaya Mengefektifkan Pendidikan Agama Islam di Sekolah. Bandung: Remaja Rosdakarya.

Syidiqi, Hasbi Asy. (1976). Pedoman Shalat. Jakarta: Bulan Bintang.

Sabri, Alisuf. (1996). Psikologi Pendidikan. Jakarta: Pedoman Ilmu Jaya.
Sudjana, (2009). Penilaian Hasil Proses Belajar Mengajar. Bandung: PT. Ramaja Rosdakarya.

Slameto, (2003). Belajar dan Faktor-faktor yang Mempengaruhinya.Jakarta: Rineka Cipta.

Soemanto, Wasty. (2006). Psikologi Pendidikan. Jakarta: PT Rineka Cipta.

Syah, Muhibbin. (2009), Psikologi Pendidikan dengan Pendekatan Baru. Bandung: Remaja Rosdakarya.

Poerwadarminta, W. J. S. (2008) . Kamus Umum Bahasa Indonesia. Jakarta: Balai Pustaka.

Uno, H. (2008). Orientasi Baru dalam Psikologi Pembelajaran. Jakarta: Bumi Aksara. 